\title{
ПРОБЛЕМЫ КАЧЕСТВА ОБРАЗОВАНИЯ
}

\section{DEVELOPING AN OPERATIONAL APPROACH TO EDUCATIONAL QUALITY ASSURANCE IN COLLEGES UNDER THE OFFICE OF THE VOCATIONAL EDUCATION COMMISSION IN THAILAND}

\author{
Chaiwichit Chianchana \\ King Mongkut's University of Technology North Bangkok, Thailand. \\ E-mail: chaiwichit.c@fte.kmutnb.ac.th \\ Sageemas Na Wichian \\ College of Industrial Technology, \\ King Mongkut's University of Technology North Bangkok, Thailand. \\ E-mail: sageemas.n@cit.kmutnb.ac.th
}

\begin{abstract}
Introduction. Improving quality assurance requires vocational education to be consistent and to be appropriate with the context of the school education. The school quality assurance operations are a driving mechanism for achieving high educational results at the next stages of education. This process will result in sustainably improving education quality.

The research aims were to assess the conditions for improving the quality of education in colleges under the Office of the Vocational Education Commission (OVEC) and to analyse and evaluate the operational approach to ensuring the quality of education.

Methodology and research methods. The study participants included college personnel directors, teachers, and staff selected through purposive sampling. A total of 44 participants were recruited for the context assessment: 28 people to analyse the operational approach and 39 people to assess the operational approach. The research tools included a record form to provide an educational quality assurance context, a questionnaire to determine the operational approach of educational quality assurance, and an assessment form to determine the operational approach of educational quality assurance. The data were analysed using percentage, mean, standard deviation, odds ratio, and content analyses.
\end{abstract}


Results and scientific novelty. The research results show that the similar contexts of education at all courses are the standard of vocational management and the standard for creating a society of learning (cooperation in creating a society of learning). Meanwhile, the differences identified are related to the peculiarities of professional qualifications and various standards for creating a learning society (innovation, inventions, creative work and research). The analysis of the operational approach allowed the authors to find out eight internal quality assurance factors for educational quality assurance: educational quality assurance planning; design of education quality assurance; study focusing on the actual operations; following the process; selection of quality indicators and criteria according to the educational context; efficient data management; following and monitoring assessments; and reviewing revised or edited assessments. Moreover, four external quality assurance factors are identified: evidence for educational quality assurance; accreditation of educational quality assurance; assessors holding appropriate qualifications; and judgment of the assessment results. In the course of the operational approach assessment, it is established that there are high levels of feasibility and appropriateness in all aspects.

The operational approach to educational quality assurance was developed using the context analysis, inputs, processes, results and concepts of internal and external quality assurance through evidence of cross-impact analysis. This method of analysis can be used to respond to educational quality assurance policy that requires that the demonstrated approach is to be easily applied in practice and requires the use of both quantitative and qualitative methods, thus creating innovations in the field of productivity-enhancing and their application in vocational education.

Practical significance. The research results can be useful for directors, teachers and staff at colleges and the Office for National Education Standards and Quality Assessment in Thailand to design and develop the methods for achieving improved quality of education on a sustainable basis.

Keywords: educational quality assurance, context assessment, operational approach, cross-impact analysis.

Acknowledgments. The authors thank the Office for National Education Standards and Quality Assessment (Public Organisation) in Thailand for providing financial support for the current research.

For citation: Chianchana C., Na Wichian S. Developing an operational approach to educational quality assurance in colleges under the Office of the Vocational Education Commission in Thailand. The Education and Science Journal. 2020; 22 (9): 67-85. DOI: 10.17853/1994-5639-2020-9-67-85 


\title{
РАЗВИТИЕ ОПЕРАТИВНОГО ПОДХОДА ДЛЯ ОБЕСПЕЧЕНИЯ КАЧЕСТВА ОБРАЗОВАНИЯ В КОЛЛЕДЖАХ ПРИ БЮРО КОМИССИИ ПО ПРОФЕССИОНАЛЬНОМУ ОБРАЗОВАНИЮ В ТАИЛАНДЕ
}

\author{
Чайвичит Чианчана \\ Технологический университет им. Короля Монгкута, Северный Бангкок, Таиланд.
} E-mail: chaiwichit.c@fte.kmutnb.ac.th

\section{Сагемас На Вичиан}

Колледж промышленных технологий, Технологический университет им. Короля Монгкута, Северный Бангкок, Таиланд.

E-mail: sageemas.n@cit.kmutnb.ac.th

Аннотация. Введение. Дия повышения качества образования необходима преемственность школьной и профессиональной подготовки. Деятельность школы по обеспечению качества образования является движущим механизмом для получения высоких образовательных результатов на следующих ступенях обучения. Успешность этой деятельности будет способствовать устойчивому повышению качества образования.

Цель исследования заключалась в оценке условий повышения качества образования в комледжах, находящихся в ведении Бюро комиссии по профессиональному образованию (OVEC), а также в анализе и оценке оперативного подхода к обеспечению качества образования.

Методология и методы исследования. В исследовании приняли участие директора по персоналу комледжа, преподаватели и персонал, отобранные посредством целенаправленной выборки. Дия оценки контекста было отобрано 44 участника: для анализа оперативного подхода - 28 человек, для его оценки - 39 человек. Исследовательские инструменты включали регистрационную форму для определения контекста обеспечения качества образования, вопросник и оценочную форму для определения оперативного подхода к обеспечению качества образования. Данные были проанализированы с помощью показателя процентной доли, среднего значения, стандартного отклонения, отношения шансов и контент-анализа.

Результаты и научная новизна. Результаты исследований показали, что сходные условия обучения на всех курсах являются стандартами профессионального управления и создания обучающегося общества (сотрудничества в его создании). В то же время выявценные разцичия были связаны с особенностями профессиональной квалификации и нешаблонными инструментами создания обучающегося общества (инновациями, изобретениями, творческой работой и исследованиями). Анализ оперативного подхода обнаружиц восемь внутренних факторов обеспечения качества образования: пманирование этого процесса; разработка системы обеспечения качества 
образования; исследование на основе фактических операций; следование процессу; подбор показатецей и критериев качества в соответствии с образовательным контекстом; эффективное управление данными; проведение последующих и контрольных оценок; обзор пересмотренных или отредактированных оценок. Также были определены четыре внешних фактора обеспечения качества образования: создание необходимых условий; аккредитация обеспечения качества образования; участие экспертов, имеющих соответствующую квалификацию; оценивание результатов оценки. В ходе оценки оперативного подхода было установцено, что по всем аспектам имеются высокие уровни реализуемости и целесообразности.

Оперативный подход к обеспечению качества образования был разработан с использованием контент-анализа, исходных данных, процессов, результатов и концепций внутреннего и внешнего обеспечения качества на основе анализа перекрестного воздействия. Этот метод анализа может применяться дмя учета политики обеспечения качества образования, согласно которой рассматриваемый подход должен быть простым в практическом применении и должен обеспечивать использование как количественных, так и качественных методов развития, способствующих созданию инноваций в области повышения производитецьности и их применению в профессиональном образовании.

Практическая значимость. Результаты исследования могут быть помезны для директоров, преподаватемей, персонала комледжей и Управления национальных стандартов образования и оценки качества (Таиланд) с цемью разработки методов устойчивого повышения качества образования.

ключевые слова: обеспечение качества образования, оценка контекста, оперативный подход, анализ перекрестного воздействия.

Благодарности. Авторы благодарят Управление национальных стандартов образования и оценки качества (Общественную организацию) (Таиманд) за оказание финансовой поддержки проведения данного исследования.

Для иитирования: Чианчана Ч., На Вичиан С. Развитие оперативного подхода для обеспечения качества образования в комледжах при Бюро комиссии по профессиональному образованию в Таиланде // Образование и наука. 2020. Т. 22, № 9. С. 67-85. DOI: 10.17853/1994-5639-2020-9-67-85

\section{Introduction}

Thailand has an ageing society, which has resulted in the country's schoolage population declining compared to other demographic groups. Consequently, classrooms and educational institutions will be closed in response to the declining number of students. Meanwhile, the number of small schools is expected to increase. Vocational and educational institutions face similar situations, meaning that the state must manage its resources for maximum efficiency and learning efficiency, while the budget must be used economically to enhance edu- 
cation quality and standards to meet the management efficiency and the changing Thai social and national contexts ${ }^{1}$. Improving education quality standards is a necessary burden for educational institutions. Education quality assurance is indispensable to enhancing quality and education standards, necessitating the review and evaluation of educational quality ${ }^{2}$.

In addition to the importance of quality assurance, education is included in the country's long-term plan (see the 2017-2036 National Education Plan in Strategy VI). This long-term plan includes developing the education management system and creating guidelines to optimise the management of educational institutions to improve the educational quality assurance system. Bringing each school context in line with national education standards and promoting the adoption of quality assurance results within the education sector should not be difficult or place a burden on teachers. This involves monitoring improvement and educational development to enhance quality and educational standards ${ }^{3}$. Educational quality assurance is not complicated and is not a burden, but it must be in line with the school context. The importance of quality assurance in education is highlighted by the vocational development plan 2017-2036 in strategy IV, which developed quality assurance systems at all levels of vocational education. This development plan focuses on systems that are consistent with changing contexts to encourage the academy to develop an effective internal quality assurance system and enhance quality in accordance with current standards ${ }^{4}$.

Improving quality assurance requires vocational education to be consistent with the context of the school and to be appropriate. The development of vocational education must be accelerated to improve the quality of vocational education. Moreover, the development of vocational education must be coordinated with the three standards of vocational education quality assurance. Assessment points include knowledge, skills, application, morals, ethics, and desirable features. The Vocational Education Programme in Vocational Education Management Collaboration is intended to build a society of learning and innovation, inventions, creative work, and research ${ }^{5}$. The context of the operational education quality assurance must be assessed for feasibility, appropriateness, and efficacy in the school context. Additionally, the school's quality assurance operations driven by educational institutions provide evidence for education quality in accordance to the educational context. This process will result in sustainably improving education quality.

${ }^{1}$ Office of the Education Council. National education plan B. E. 2560-2579. Bangkok: Prigwhan Graphic; 2017. 228 p.

${ }^{2}$ Office of the Higher Education Commission. Guideline of internal quality assurance on higher education B. E. 2557. 3rd ed. Bangkok: Pappim; 2017. 160 p.

${ }^{3}$ Office of the Education Council. National education plan B. E. 2560-2579. Bangkok: Prigwhan Graphic; 2017. 228 p.

${ }^{4}$ Office of the Vocational Education Commission. Vocational development plan B. E. 2560 - B. E. 2579. Bangkok: Office of the Vocational Education Commission; 2017. 74 p.

${ }^{5}$ Royal Thai Government Gazette. Ministry of education announcement for vocational education standards B. E. 2561. Vol. 135, Special 228 D. Bangkok: Government Gazette; 2018. 3 p. 


\section{Research Objectives}

The research objectives were as follows: to assess the context of educational quality assurance in colleges under the Office of the Vocational Education Commission; to analyse the operational approach of educational quality assurance in the colleges through cross-impact analysis; and to assess the operational approach of educational quality assurance in the colleges.

\section{Literature Review}

The significance of quality assurance

The current quality assurance for Thailand's vocational education has established a new plan that focuses on systems that are consistent with changing contexts to encourage academies to develop a quality assurance system ${ }^{1}$. Quality assurance has its roots in large-scale manufacturing, and it is a process that requires transparency and the dissemination of results to all the stakeholders [1] since the improvement, self-awareness and self-reflection of the institution and a set of processes are centrally managed and guided by external requirements [2].

Quality assurance is focused on providing confidence that quality requirements are fulfilled [3], and it is focused on the constructed procedures that the institution has implemented to ensure that a design meets quality standards. Quality assurance in education, like quality planning, quality control and quality improvement, is a means of implementing quality policy objectives and responsibilities within a quality system at all levels of the education system [4]; furthermore, it is the process of implementing consistent and continuous management education quality.

Vocational education is an education unit whose mission is to develop professional attitudes, the ability to compete, and the ability to work and to have a career. Quality-assurance systems play an important part in the lives of most people who work in or who are in contact with the vocational education and training (VET) system [5]. Quality assurance includes the processes and procedures that systematically monitor different aspects of a service, process or facility to detect, correct and ensure quality. MacDonald, Nink, and Duggan [6] agree that a high-quality system can serve as the impetus to boost the economic value of a nation and its GDP in the global marketplace. In addition, the process of establishing quality standards involves the assessment of all stakeholders, including the institutions [7].

Quality assurance in vocational education has an important function in achieving process control, transparency and accountability. There is an increasing interest in quality assurance standards due to the increase in the number of students [8]. Furthermore, quality assurance is most effective when it reflects the relationship between research, learning, and teaching and takes account of the national context in which the institution operates, the institu-

${ }^{1}$ Office of the Vocational Education Commission. Vocational development plan B. E. 2560 - B. E. 2579. Bangkok: Office of the Vocational Education Commission; 2017. 74 p.

Образование и наука. Том 22, № 9. 2020 / The Education and Science Journal. Vol. 22, № 9. 2020 
tional context and its strategic approach ${ }^{1}$. Efficient and qualified vocational education is the education that can provide students with real experience with tools, machines, materials, and work methods. The current concept of quality assurance is expected to guarantee the quality of holistic students [9]. This means that students' learning outcomes are what measure the quality of vocational education.

\section{The operational approach}

Students' learning outcomes are important measures of the quality of vocational education. The educational quality is guaranteed through the context, input, processes, and results with respect to learning outcomes. Quality assurance is important for accountability and to support the ongoing development of schools, teaching and learning ${ }^{2}$.

Babalola [4] mentions that quality indicators related to the context are important in the analysis of educational context, the development of quality assurance and setting the context that is important to quality assurance ${ }^{3}$. The context that is measured should be determined to be useful in research and for interpretation in organisational decision-making about quality improvement investments [10]. In addition to the importance of the context, researchers should examine the multidimensional concepts of quality from three interrelated dimensions: the quality of the human and material resources available (inputs), the quality of the management and teaching / learning processes taking place (process), and the quality of the results (outputs or outcomes) [4, $11,12]$. The quality of the inputs, processes and outputs have to be combined with the demands put forward by students each time one intends to assess quality [13].

The operational approach to quality assurance includes internal and external quality assurance [14]. Internal quality assurance includes the mechanisms for enacting the meaning of quality, and external quality assurance includes the mechanisms for guaranteeing the meaning of quality [15].

The operational approach to quality assurance can include mechanisms that are external and internal to schools. Internal mechanisms may include school self-evaluations, staff appraisals and classroom-based student assessments [16]. External mechanisms may include national or regional school evaluations and / or large-scale student assessments ${ }^{4}$. This means that the operational approach to quality assurance to guarantee learning outcomes must be composed of operational relationships related to the analysis of the context, inputs, processes, and results under internal and external quality assurance.

\footnotetext{
${ }^{1}$ European Higher Education Area. Standards and guidelines for quality assurance in the European Higher Education Area (ESG). Brussels: ESG; 2015. 32 p.

2 European Commission. Quality assurance for school development. 2nd ed. Brussels: European Commission; 2018. 41 p.

${ }^{3}$ International Pharmaceutical Federation. Quality assurance of pharmacy education: The FIP global framework. 2nd ed. The Hague: International Pharmaceutical Federation; 2014. 40 p.

${ }^{4}$ European Commission. Quality assurance for school development. 2nd ed. Brussels: European Commission; 2018. 41 p.
} 


\section{Developing an operational approach}

The development strategies of the operational approach can be used in order to enhance their competitiveness in quality assurance in education [17, $18,19]$. The approach that is developed must be simple and easy to use and include evaluative tools and indicators that can be used to support their effective implementation [20, 21].

Therefore, this approach has been developed under an effective approach that is easy to practice. There is a link in the planning, conducting, management, follow-up, review and judgment based on both qualitative and quantitative evidence and assessment evidence. This research has been used to provide evidence of the cross-impact analysis between internal and external quality assurance. Gordon [22] states that the cross-impact method is an analytical approach to the probabilities of a list in a forecasted set. Its probabilities can be adjusted in view of the judgments concerning the potential interactions among the forecasted lists.

The operational approach to educational quality assurance is a strategy to maintain the quality and educational standards of the educational institutions affiliated with the Office of Vocational Education. The context assessment of the vocational quality assurance, which evaluates vocational standards and the educational context, led to the design of an operational approach to educational quality assurance in accordance with the inputs, process, and results under internal quality assurance and external quality assurance. This is performed through the evidence provided by cross-impact analysis, as well as the results of the operational approach to educational quality assurance of the study, which are evaluated to reflect their feasibility and appropriateness. This is the conceptual framework of the research, as shown in Figure 1.

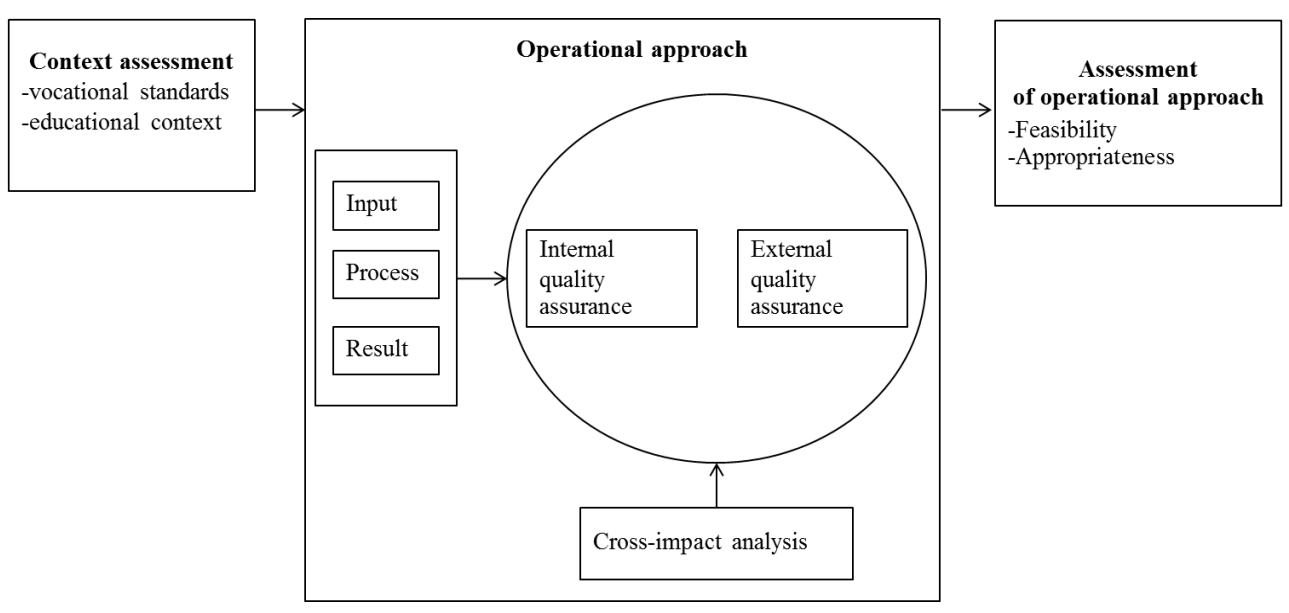

Fig. 1. Conceptual framework of research 


\section{Research Methodology}

Figure 2 and the following section outline the research methods used in each step of this research, including a description of the data sources, research instruments, and data analysis used in the study.

\begin{tabular}{|c|c|c|c|c|}
\hline \multirow{2}{*}{$\begin{array}{l}\text { Assess the } \\
\text { context of } \\
\text { educational } \\
\text { quality } \\
\text { assurance }\end{array}$} & $\begin{array}{l}\text { Result of } \\
\text { context to the } \\
\text { analysis the }\end{array}$ & \multirow{2}{*}{$\begin{array}{l}\text { Analyse the } \\
\text { operational } \\
\text { approach of } \\
\text { educational } \\
\text { quality } \\
\text { assurance }\end{array}$} & $\begin{array}{l}\text { Result of the } \\
\text { operational } \\
\text { approach }\end{array}$ & \multirow{2}{*}{$\begin{array}{l}\text { Assess the } \\
\text { operational } \\
\text { approach of } \\
\text { educational } \\
\text { quality } \\
\text { assurance }\end{array}$} \\
\hline & $\begin{array}{l}\text { operational } \\
\text { approach }\end{array}$ & & $\begin{array}{l}\text { to the } \\
\text { assessment }\end{array}$ & \\
\hline
\end{tabular}

Fig. 2. Research steps and methods

\section{Assessing the educational quality assurance context}

Data sources: 1) documents on quality assurance, courses, and vocational standards; 2) documents on educational quality assurance at vocational colleges, technical colleges, industrial and community colleges, polytechnic colleges, and agricultural and technology colleges spanning 3 years; and 3) directors, teachers, and staff relevant to the educational quality assurance of the aforementioned educational institutions who were selected through purposive sampling according to each college type (44 individuals). Guest, Bunce and Johnson [23] suggest that a carefully selected sample of 12 participants is likely sufficient.

Research instruments: 1) researcher's record form and the interview forms for the directors, teachers, and staff on the context of educational quality assurance, as verified by five experts, the results of which are in the appropriate language for all items; and 2) questionnaire for the educational quality assurance context (appropriate for indicators and context) completed by the directors, teachers, and staff and verified by five experts, with the results appearing in the appropriate language for all items.

Data analysis: the data from the record and interview forms was analysed using content analysis, whereas the questionnaire data were analysed by percentage.

2. Analysis of the operational approach of educational quality assurance

Data sources: directors, teachers, and staff related to the educational quality assurance at vocational colleges, technical colleges, industrial and community colleges, polytechnic colleges and agricultural and technology colleges who were selected through purposive sampling according to each college type (28 individuals). Guest, Bunce and Johnson [23] suggest a carefully selected sample of 12 participants is likely sufficient.

Research instruments: the questionnaire on the operational approach of educational quality assurance, which was completed by the directors, teachers, and staff (used in the cross-impact analysis), was verified by five experts, and the results had an index of consistency between 0.80-1.00.

Data analysis: the operational approach of educational quality assurance data was analysed using the odds ratio. 
3. Assessment of the operational approach of educational quality assurance

Data sources: directors, teachers, and staff related to the educational quality assurance at vocational colleges, technical colleges, industrial and community colleges, polytechnic colleges and agricultural and technology colleges who were selected by purposive sampling according to each college type (39 individuals). Guest, Bunce and Johnson [23] suggest a carefully selected sample of 12 participants is likely sufficient.

Research instruments: 1) the manual for the operational approach to educational quality assurance was verified by experts, with the results showing that it was suitable for studying the selected sample group, appropriate for the principles to be applied, and easy to read and uncomplicated; 2) the assessment form for the operational approach of educational quality assurance for directors, teachers, and staffs was verified by five experts, with the results suggesting an index of consistency between 0.80-1.00, which in some respects should be easily adjusted to understand the language; the item-total correlation was between $0.20-0.83$, and a Cronbach's alpha coefficient of 0.89 .

Data analysis: the data from the manual for the operational approach to educational quality assurance was analysed by content analysis, whereas data from the assessment of the operational approach of educational quality assurance were analysed using the mean and standard deviation.

\section{Results}

1. Context assessment results of educational quality assurance in vocational education

Table 1 outlines the context assessment results for vocational education while considering the quality assurance of the curricula and vocational standards.

Table 1

Similar and different contexts of educational quality assurance in vocational education

\begin{tabular}{|c|c|}
\hline Similar contexts & Different contexts \\
\hline $\begin{array}{l}\text { 1) All aspects of } \\
\text { standards for vocational } \\
\text { management. } \\
\text { 2) Standards for the } \\
\text { creation of a society of } \\
\text { learning (cooperation in } \\
\text { the creation of a society of } \\
\text { learning). }\end{array}$ & $\begin{array}{l}\text { 1) All aspects of standard features for professional } \\
\text { vocational qualifications. In the vocational certificate } \\
\text { programme, high vocational certificate programme, } \\
\text { and Bachelor programme, explicit handling as specified } \\
\text { in a mess, but the arrangement of short courses and } \\
\text { informal courses depended on each course. } \\
\text { 2) Standards in creating a society of learning } \\
\text { (innovation, invention, creative work, research) in } \\
\text { the vocational certificate programme, high vocational } \\
\text { certificate programme, and Bachelor programme. } \\
\text { There was an apparent emphasis on innovation, } \\
\text { invention, creative work, and research; however, } \\
\text { short courses and free courses did not focus on } \\
\text { innovation, invention, creative work, and research. }\end{array}$ \\
\hline
\end{tabular}


In addition, the results of the context assessment regarding the appropriateness between the indicators and the context of vocational education depend on the college type (vocational, technical, industrial and community, polytechnic, and agriculture and technology). When considering the appropriateness of the indicators and the vocational education context, 30\% was used as a criterion to determine the biased opportunities of the test based on inappropriateness. If over $30 \%$ of the comments are made, the indicator is likely to be biased against certain schools [24]. The results show 25 indicators. A chance for discrepancies was found. There are 11 indicators: 1) care and guidance; 2) learners can become entrepreneurs or freelancers; 3) the work of innovative learners, inventions, creative work, or research; 4) professional skill results; 5) professional standard assessment results; 6) national educational results in vocational education (V-NET); 7) systematic development of performance-based courses; 8) developing performance-based courses or improving original subjects or additional subjects; 9) self-development and professional development; 10) mobilising resources for teaching arrangement; and 11) high-speed internet access for classroom teaching.

2. Analytical results for the operational approach to educational quality assurance using cross-impact analysis

The context assessment results of the educational quality assurance of vocational education led to an analysis of the operational approach to educational quality assurance.

The probability of an incident in the study of the quality assurance approach was calculated from the mean of the percentage, with the probability of an event occurring calculated to be $100 \%$. This value reflects the potential for an incident and provides the best approach possible for quality assurance. The highest probability was used as evidence for educational quality assurance (External Quality Assurance: EQA) $=0.75$, whereas the lowest probability was the review of the revised or edited assessment (Internal Quality Assurance: IQA) $=0.45$.

The odds-ratio was calculated by the ratio between the probability of an event and the probability of no incident occurring. The highest odd-ratio value (initial) was evidence for educational quality assurance (EQA) $=3.00$, whereas the lowest value was for the review of the revised or edited assessment $(\mathrm{IQA})=0.82$.

The highest odds-ratio of an impact event was used as evidence for educational quality assurance (EQA), which affected the selection of quality indicators and criteria according to the educational context $=32.33$. The lowest odds-ratio of an impact event was the design of education quality assurance (IQA), which affected the accreditation of educational quality assurance $(\mathrm{EQA})=0.30$.

The impact index was calculated from the odds-ratio of one event which caused another event to the normal ratio. This value reflects one event that significantly affected other events, considering values greater than 1.00 [22], which the approach of the educational quality assurance the impact of other approaches, as shown in Table 2. 
Approach to educational quality assurance and the impact of other approaches that followed

\begin{tabular}{|c|c|}
\hline Approach & The impact of other approaches which followed \\
\hline $\begin{array}{l}\text { Judgment of the } \\
\text { assessment results (EQA) }\end{array}$ & $\begin{array}{l}\text { Five approaches: } \\
\text { 1) Plan of educational quality assurance planning } \\
\text { (IQA) }=1.34 \text {. } \\
\text { 2) Selection of quality indicators and criteria } \\
\text { according to the educational context (IQA) }=1.33 . \\
\text { 3) Efficient data management (IQA) }=1.08 . \\
\text { 4) Following and monitoring assessments (IQA) }=1.04 \text {. } \\
\text { 5) Reviewing revised or edited assessments (IQA) }=1.04 \text {. }\end{array}$ \\
\hline Follow the $\mathrm{p}$ & $\begin{array}{l}\text { Three approaches: } \\
\text { 1) Following and monitoring assessments (IQA) }=1.12 \text {. } \\
\text { 2) Efficient data management (IQA) }=1.00 . \\
\text { 3) Reviewing revised or edited assessments (IQA) }=1.00 \text {. }\end{array}$ \\
\hline $\begin{array}{l}\text { Desi } \\
\text { assu }\end{array}$ & $\begin{array}{l}\text { Two approaches: } \\
\text { 1) Selection of quality indicators and criteria } \\
\text { according to the educational context (IQA) }=1.08 \text {. } \\
\text { 2) Following the process (IQA) }=1.00 \text {. }\end{array}$ \\
\hline $\begin{array}{l}\text { Efficient data management } \\
\text { (IQA) }\end{array}$ & $\begin{array}{l}\text { Two approaches: } \\
\text { 1) Following and monitoring assessments (IQA) }=1.22 \text {. } \\
\text { 2) Reviewing revised or edited assessments (IQA) }=1.08 \text {. }\end{array}$ \\
\hline $\begin{array}{l}\text { Educ } \\
\text { assu }\end{array}$ & $\begin{array}{l}\text { Selection of quality indicators and criteria according } \\
\text { to the educational context (IQA) }=1.51 \text {. }\end{array}$ \\
\hline $\begin{array}{l}\text { Actual operations study } \\
\text { (IQA) }\end{array}$ & $\begin{array}{l}\text { Selection of quality indicators and criteria according } \\
\text { to the educational context (IQA) }=1.04 \text {. }\end{array}$ \\
\hline $\begin{array}{l}\text { Selection of quality } \\
\text { indicators and criteria } \\
\text { according to the educational } \\
\text { context (IQA) }\end{array}$ & Efficient data management $(\mathrm{IQA})=1.04$. \\
\hline $\begin{array}{l}\text { Following and monitoring } \\
\text { assessments (IQA) }\end{array}$ & vised or edited as \\
\hline $\begin{array}{l}\text { Reviewing revised or edited } \\
\text { assessments (IQA) }\end{array}$ & Following and monitoring assessments (IQA) $=1.00$. \\
\hline $\begin{array}{l}\text { Evidence for educational } \\
\text { quality assurance (EQA) }\end{array}$ & $\begin{array}{l}\text { and criteria according } \\
)=28.61\end{array}$ \\
\hline $\begin{array}{l}\text { Accreditation of educational } \\
\text { quality assurance (EQA) }\end{array}$ & $\begin{array}{l}\text { Selection of quality indicators and criteria according } \\
\text { to the educational context (IQA) }=1.44 \text {. }\end{array}$ \\
\hline $\begin{array}{l}\text { Assessors hold appropriate } \\
\text { qualifications(EQA) }\end{array}$ & $\begin{array}{l}\text { Selection of quality indicators and criteria according } \\
\text { to the educational context (IQA) }=1.22 \text {. }\end{array}$ \\
\hline
\end{tabular}

Cross-impact analysis indicates that each approach has a shared impact. The assessment of operational approaches for educational quality assurance in the colleges found eight factors that contributed to internal education quality assurance: educational quality assurance planning; design of education qual- 
ity assurance; study focusing on the actual operations; following the process; selection of quality indicators and criteria according to the educational context; efficient data management; following and monitoring assessments; and reviewing revised or edited assessments. Meanwhile, four factors contributed to external education quality assurance: evidence for educational quality assurance; accreditation of educational quality assurance; assessors holding appropriate qualifications and judgment of the assessment results. Figure 3 illustrates the approach for implementing implement educational quality assurance.

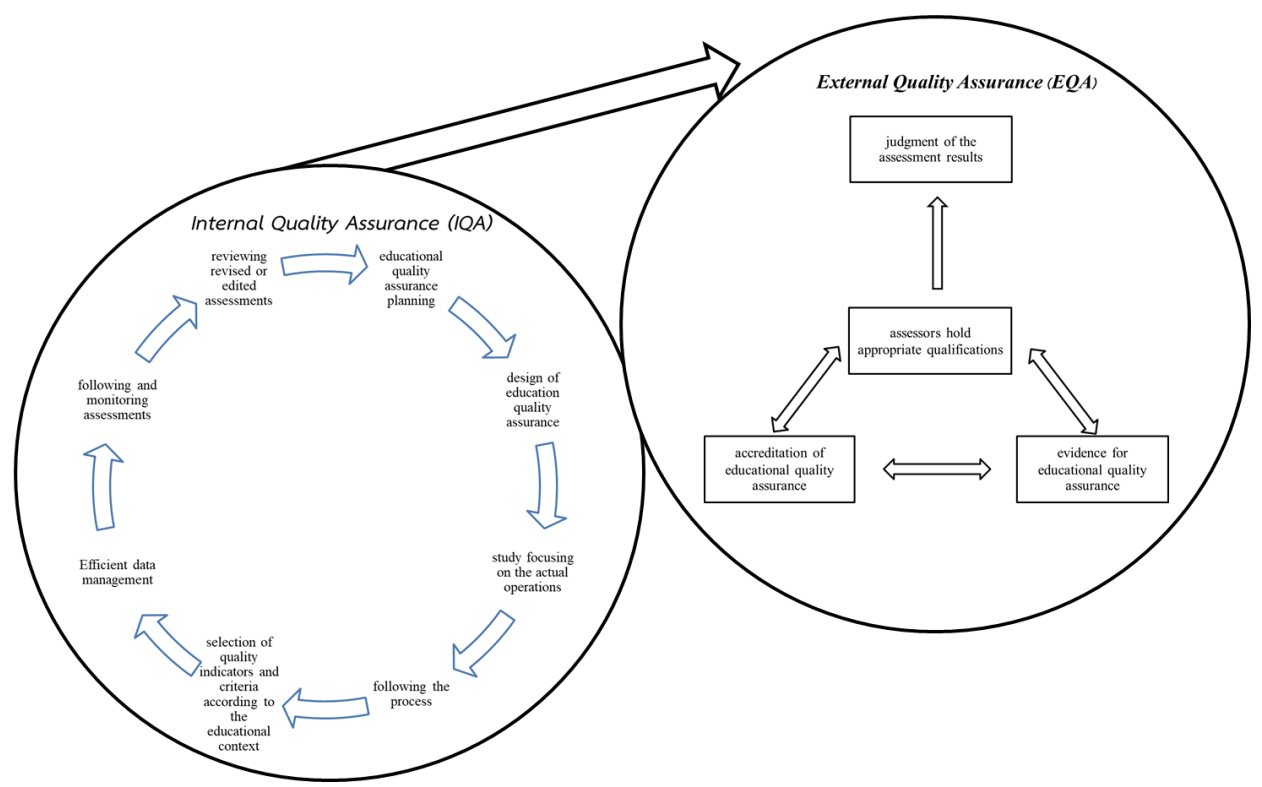

Fig. 3. Operational approach for educational quality assurance.

3. Assessment results for the operational approach to educational quality assurance

The results of the operational approach to educational quality assurance lead to assessment considered through the manual of operational approach to educational quality assurance, which consisted of objectives, processes, and content.

The assessment results show that the operational approach to educational quality assurance had high levels of feasibility and appropriateness for all items. Additionally, educational quality assurance should be implemented to achieve sustainable development among the colleges, and the following positive comments regarding quality assurance were received:

"The educational quality assurance needs to be done, sustainable and everyone wants to do it".

"The educational quality assurance, most people do it, people don't do it, so they want everyone to help with quality assurance". 
"The educational quality assurance wants to be sustainable, even if we have modified indicators and criteria, we should have a way to develop lead to sustainability and cooperation".

Table 3 demonstrates the results from the operational approach to educational quality assurance assessment.

Table 3

Operational approach for educational quality assurance assessment results

\begin{tabular}{|c|c|c|c|c|}
\hline \multicolumn{2}{|r|}{ Item } & Mean & $\mathrm{S}$ & $\begin{array}{l}\text { Assessment } \\
\text { Level }\end{array}$ \\
\hline \multicolumn{5}{|c|}{ Feasibility } \\
\hline 1. & The approach can be conducted in practice. & 4.15 & 0.49 & High \\
\hline 2. & $\begin{array}{l}\text { It is possible that the stakeholders will accept the } \\
\text { approach. }\end{array}$ & 4.03 & 0.54 & High \\
\hline 3. & $\begin{array}{l}\text { It is possible for the approach to achieve good } \\
\text { operational results. }\end{array}$ & 4.03 & 0.67 & High \\
\hline \multicolumn{5}{|c|}{ Appropriateness } \\
\hline 4. & The approach can be conducted effectively. & 4.21 & 0.57 & High \\
\hline 5. & $\begin{array}{l}\text { The approach can respond thoroughly to the } \\
\text { relevant person. }\end{array}$ & 3.97 & 0.71 & High \\
\hline 6. & Those involved can accept the approach in practice. & 4.13 & 0.61 & High \\
\hline 7. & $\begin{array}{l}\text { The approach can be conducted without negatively } \\
\text { affecting the stakeholders. }\end{array}$ & 4.26 & 0.72 & High \\
\hline 8. & $\begin{array}{l}\text { The approach can be conducted fairly with all } \\
\text { parties. }\end{array}$ & 4.10 & 0.64 & High \\
\hline 9. & The approach can be reported honestly. & 4.18 & 0.76 & High \\
\hline 10. & $\begin{array}{l}\text { The approach can be appropriately applied to the } \\
\text { educational context. }\end{array}$ & 4.31 & 0.66 & High \\
\hline
\end{tabular}

\section{Discussion}

1. The operational approach allowed for both internal and external educational quality assurance. Other approaches had different consequences. The judgement of the assessment result had the greatest impact on the other consequences (external quality assurance), in which the assessment results are considered by the assessor and information from the assessment results is updated continuously. This may be due to consideration of the assessment report results and the external quality assurance process. The external quality assurance process is the final step of the studied approach and is a destination that must be processed following other approaches from the beginning, which results in opportunities for many other approaches to be affected. According to the concept of the International Pharmaceutical Federation ${ }^{1}$ and the Tertiary

${ }^{1}$ International Pharmaceutical Federation. Quality assurance of pharmacy education: The FIP global framework. 2nd ed. The Hague: International Pharmaceutical Federation; 2014. 40 p. 
Education Services Office ${ }^{1}$, assessment results for external quality assurance are considered via the judgment of specialists who carefully consider the trust to lead to acceptance, which is highly important. Furthermore, Endut [16] and the Ministry for Education and Employment ${ }^{2}$ discussed that the results of external quality assessments and the conduct of external quality assessment results that are considered by the assessor will be a confidence-building exercise and seek to encourage compliant actions with internal quality assurances that have previously been completed.

2. From the findings, the operational approach to internal quality assurance consisted of eight factors, whereas external quality assurance consisted of five factors. A number of potential aspects of practice and appropriate action can be taken that have similarities with previous college compliance guidelines, such as plan-do-check-act. Rukthai and Eungpuang [25], Patel and Deshpande [26], Khunaphrom and Phuapaiboon [27] and Kotvitska, et al [28] utilised five consistent research approaches: preparing a developmental plan; system and information management; implementation of the developmental plan for educational management; monitoring education quality; and managing the development of educational quality development. Additionally, Harper and John [29] used two consistent research approaches and found that quality assurance and development planning are two motivations for organisational structural change when the research participants are confident in the college development plan framework.

\section{Conclusion}

1. The context of educational quality assurance for vocational education was considered in relation to the quality assurance of curriculums and vocational standards. In similar contexts, all of the course management curriculums included: 1) a standard of vocational management in all aspects; 2) standards for creating a society of learning (cooperation in the creation of the society of learning). Meanwhile, the differing contexts included: 1) all aspects of standard features in professional vocational qualifications, and in particular, the vocational certificate programme, high vocational certificate programme, and Bachelor programme and explicit handling as specified in a mess, but the arrangements of short courses and informal courses were course dependent; 2) standards for creating a society of learning (innovation, invention, creative work, and research) in the vocational certificate programme, high vocational certificate programme, and Bachelor programme with an apparent emphasis on innovation, invention, creative work, and research, yet these were not the focus of the short and free courses.

2. The findings of the operational approach to educational quality assurance in the colleges found that internal education quality assurance consists of

\footnotetext{
${ }^{1}$ Tertiary Education Services Office. Higher education quality evaluation of Macao. Macao: Tertiary Education Services Office; 2018. 47 p.

${ }^{2}$ Ministry for Education and Employment. Internal and external quality assurance in further and higher education. Malta: Ministry for Education and Employment; 2013. 12 p.
} 
eight factors: the plan of educational quality assurance planning; the design of education quality assurance; studies focused on the actual operation; follow the process; selection of quality indicators and criteria according to the educational context; efficient data management; following and monitoring assessments; and reviewing revised or edited assessments. Meanwhile, the external education quality assurance consists of four factors: evidence for educational quality assurance; accreditation of educational quality assurance; assessors holding appropriate qualifications; and judgment of the assessment results. From the cross-impact analysis, the most effective approach to the other impact was judgment of the assessment results (external education quality assurance). There were five other factors in the following way.

3 . The results of the assessment of the operational approach to educational quality assurance in the colleges found that feasibility and propriety had high levels in all items. Meanwhile, the quality assessment found that the study of the quality assurance operation should be conducted to contribute to sustainable development in the colleges and develop positive attitudes towards educational quality assurance.

\section{Recommendations}

From the present study, a number of suggestions are made for implementing further research. First, eight internal quality assurance approaches should be used for the operation of educational quality assurance since this approach allows colleges to determine the direction of their internal quality assurance so they can ensure that the quality assurance context of vocational education is related to the actual context. This adheres to the curriculum context that organises teaching, within which uniqueness, similarities, and differences were found. Second, indicators and criteria should be defined following the different educational quality assurance contexts based on course characteristics. Navigating the course context allows the indicators and criteria to be defined for educational quality assurance. Third, future research should aim to improve participation and attitudes toward quality assurance so that educational institutions can achieve sustainable development. The implementation of educational quality assurance practices can include activities such as training, short films, and self-learning manuals.

This research makes a number of suggestions for future research. Firstly, research, implementation, and evaluation regarding use of the operational approach to educational quality assurance in educational institutions should be conducted according to the nature of the college in the Vocational Education Committee. Secondly, research should be conducted on the model of the judgment of the assessment results for educational quality assurance based on the educational context. Finally, future research should be pursued to study misconceptions surrounding internal and external quality assurance processes. 


\section{References}

1. Joshi M. A. Quality assurance in medical education. Indian Journal of Pharmacology. 2012; 44 (3): 285-287.

2. Rosa M., Cardoso S., Videira P., Amaral A. Internal quality assurance: A new culture or added bureaucracy? Assessment \& Evaluation in Higher Education. 2019; 4 (2): 249-262.

3. Manghani K. Quality assurance: Importance of systems and standard operating procedures. Perspectives in Clinical Research. 2011; 2 (1): 34-37.

4. Babalola J. B. Quality assurance in education: Input, process and output. Edited by Ayeni A. O., Emetarom U. G., Nwafor S. O., Atanda A. I. In: Educational management, environmental literacy and climate change. Nigeria: National Association of Educational Administration and Planning (NAEAP); 2010. p. 281-298.

5. Gunning D. Quality assurance in vocational education and training. International Encyclopedia of Education (Third Edition). 2010. p. 482-488.

6. MacDonald S., Nink K., Duggan S. Principles and strategies of a successful TVET programme [Internet]. Centerville, UT: MTC Institute; 2010 [cited 2020 May 20]. 16 p. Available from: http://www.mtctrains.com/public/uploads/1/2011/3/International\%20TVET \%202010.pdf7.

7. Morris H. A. Revisiting quality assurance for TVET in the Caribbean. Caribbean Curriculum. 2013; 21: 121-148.

8. Cetinsaya G. A road map for Turkish higher education, growth quality internalization, higher education council publication. Eskişehir: Anadolu Üniversitesi Basımevi; 2014. 25 p.

9. Munastiwi $\mathrm{E}$. The management model of vocational education quality assurance using 'holistic skills education (Holsked)'. Procedia - Social and Behavioral Sciences. 2015; 204: 218-230.

10. Kathryn M., McDonald M. M. Considering context in quality improvement interventions and implementation: Concepts, frameworks, and application. Academic Pediatrics. 2013; 13 (6S): 45-53.

11. Galvão M. E. Making the case for vocational education and training improvement: Issues and challenges. Ed. by European Training Foundation. In: Quality assurance in vocational education and training. Turin: European Training Foundation; 2014. p. 5-16.

12. Salam A. Input, process and output: system approach in education to assure the quality and excellence in performance. Bangladesh Journal of Medical Science. 2015; 14 (1): 1-2.

13. Sarrico C. S., Rosa M. J., Teixeira P. N., Cardoso M. F. Assessing quality and evaluating performance in higher education: Worlds apart or complementary views? Minerva. 2010; 48: 35-54.

14. Stukalina Y., Roskona A. Management of a study programme in the context of quality assurance in higher education. In: Proceedings of the 11th International Scientific Conference 2018; 2018; Jelgava. Jelgava: Latvia University of Life Sciences and Technologies; 2018. p. 118-127.

15. Ansah F. Conceptualising external and internal quality assurance in higher education: A pragmatist perspective. International Journal of African Higher Education. 2015; 2: 135-152. 
16. Endut A. S. Enhancing internal quality assurance mechanism at HEI through responsive program evaluation. Procedia - Social and Behavioral Sciences. 2014; 123: 5-11.

17. Fadeeva Z., Galkute L., Mader C., Scott G., Mohun S. Sustainable development and quality assurance in higher education. UK: Palgrave Macmillan; 2014. 284 p.

18. Powdthavee N., Lekfuangfu W. N., Wooden M. What's the good of education on our overall quality of life? A simultaneous equation model of education and life satisfaction for Australia. Journal of Behavioral and Experimental Economics. 2015; 54: 10-21.

19. Yirdaw A. Quality of education in private higher institutions in Ethiopia: The role of governance. SAGE Open. 2016; 6 (1): 1-12.

20. Alam M. M. Quality assurance in school education. Learning Community: An International Journal of Educational and Social Development. 2015; 6 (1): 163-169.

21. Summers B. L. Effective processes for quality assurance. Pharmaceutical Regulatory Affairs. 2017; 6 (1): 1-3.

22. Gordon T. J. Cross-impact method. Ed. by Glen J. C. In: Futures Research Methodology Version 1. Washington: American Council for the United Nations University; 1994. p. 1-10.

23. Guest G., Bunce A., Johnson L. How many interviews are enough? Field Methods. 2006; 18: 59-82.

24. Zieky M., Perie M. A primer on setting cut scores on tests of educational achievement. New Jersey: Educational Testing Service; 2006. 26 p.

25. Rukthai N., Eungpuang A. Guideline to operate internal quality assurance in the basic school for external evaluation under the office of secondary service Area 21. Journal of Education. 2015; 38 (2): 48-55.

26. Patel P. M., Deshpande V. A. Application of plan-do-check-act cycle for quality and productivity improvement - a review. International Journal for Research in Applied Science \& Engineering Technology. 2017; 5 (I): 197-201.

27. Khunaphrom N., Phuapaiboon M. Guidelines of internal educational quality assurance implementation in schools under chaiyaphum provincial administrative organization. Journal of Administration and Supervisor, Mahasarakham University. 2018; 9 (1): 121-132.

28. Kotvitska A., Lebedynets V., Karamavrova T. The PDCA cycle implementation at the internal audit process of quality management systems of pharmaceutical companies. The Pharma Innovation Journal. 2019; 8 (2): 709-713.

29. Harper J. R. The role of teams in quality assurance and improvement planning in two Illinois middle school. Dissertation Abstracts International. 2000; 61 (1): 41-A.

\section{Information about the authors:}

Chaiwichit Chianchana - Associate Professor of Educational Research, Faculty of Technical Education, King Mongkut's University of Technology North Bangkok, Thailand. E-mail: chaiwichit.c@fte.kmutnb.ac.th 
Sageemas Na Wichian - Associate Professor of Educational Research, College of Industrial Technology, King Mongkut's University of Technology North Bangkok, Thailand. E-mail: sageemas.n@cit.kmutnb.ac.th

Received 05.07.2020; accepted for publication 07.10.2020.

The authors have read and approved the final manuscript.

\section{Contribution of the authors:}

C. Chianchana developed the research topic, conduced data collection, performed data analysis and interpretation, and wrote the research paper.

$\mathrm{S}$. Na Wichian provided a literature review, and performed data analysis.

Ннформачия об авторах:

Чайвичит Чианчана - доцент исследований в области образования факультета технического образования Технологического университета им. Короля Монгкута, Северный Бангкок, Таиланд. E-mail: chaiwichit.c@fte. kmutnb.ac.th

Сагемас На Вичиан - доцент исследований в области образования Комледжа промышленных технологий Технологического университета им. Короля Монгкута, Северный Бангкок, Таиланд. E-mail: sageemas.n@cit. kmutnb.ac.th

Статья поступила в редакцию 05.07.2020; принята в печать 07.10.2020. Авторы прочитали и одобрили окончательный вариант рукописи.

\section{Вклад соавторов:}

Ч. Чианчана - разработка темы исследования, сбор данных, анализ и интерпретация данных, подготовка текста научной публикации.

С. На Вичьян - обзор митературы, анализ данных. 